\title{
IN-VITRO ANTIFUNGAL ACTIVITY OF GANDHAKA RASAYANA
}

\section{Prasanna Kumar $T^{*}$, Vijay Kumar $G S^{l}$, Yumnam Dhanesori Devi ${ }^{2}$}

\author{
${ }^{1}$ Professor and HOD, Department of Microbiology, JSS Medical College, Mysore, \\ ${ }^{2}$ P.G. Scholar, Department of P.G. Studies in Rasashastra, JSS Ayurveda Medical College, Mysore, \\ dr.dhanesori@gmail.com
}

\begin{abstract}
Many herbo-mineral remedies individually or in combination have been recommended in various medical treatises for the cure of different diseases. Gandhaka Rasayana is a compound preparation, being used by Ayurvedic physicians in clinical practice for thousands of years, in the treatment of skin diseases of bacterial and fungal origin. So the drug is selected to study its anti-fungal effect on Candida albicans. Candidiasis is the most common mycotic disorder of the skin affecting the immune-compromised patients and those on the anti-biotic therapy. Hence the anti-candidal activity was examined in the study. For the study Broth Dilution method was adopted to study the Minimum Inhibitory Concentration (MIC) and Minimum Contact Time (MCT) of the Gandhaka Rasayana, following NCCLS guidelines. Results: Gandhaka rasayana showed antifungal effect against Candida albicans with Minimum inhibitory concentration (MIC) of $5.00 \mathrm{mg} / \mathrm{ml}$ of Brain Heart Infusion (BHI) Broth and Minimum Contact Time (MCT) above one hour.
\end{abstract}

Key words: Candidiasis, Minimum inhibitory concentration, Minimum contact time, Gandhaka rasayana,

\section{Introduction:}

Fungal diseases of the skin can be divided into superficial mycoses and deep mycoses. Superficial mycoses are infections restricted to invasion of horny structures like the stratum corneum while the deep mycoses infect deeper layers. Deep mycoses are much more common in immunocompromised patients including these with AIDS, transplanted patients on corticosteroid or immuno-suppressive therapy. Candidiasis is one of the most common fungal infections affecting both the superficial as well as deeper layers of the skin and mucous membranes. Though candidiasis can be caused by various species of Candida (like C. albicans, C.stellatoidea

\footnotetext{
* Corresponding Author:

Assistant professor, Department of P.G. Studies in Rasashastra, JSS Ayurveda Medical College, Mysore,

E-Mail: drprasannakumart@,gmail.com,

Tel: +91-9916482581
}

tropicalis, C. krusei, C. viswanathii etc), Candida albicans is a causative species in about $80-90 \%$ of cases. Candida albicans is a normal inhabitant of gastro-intestinal tract, oral and vaginal cavities. Various manisfestation of candidiasis include mucocutaneous lesions (like oral thrush, vulvovaginitis, conjunctivitis etc), various skin and nail infections (commonly found in areas macerated by perspiration like axillae, groin, perineum, diapered area of infants, etc). Deeply invasive candidiasis is often preceded by increased superficial colonization of mouth, vagina, GIT, skin etc., mostly following broad spectrum antibiotic therapy. Factors which decrease the immune-competence of the person (e.g.: diabetes mellitus, HIV infections, corticosteroid therapy etc.) favour its growth. Candida can pass from colonized surface into deep tissue when integrity of skin or mucosa is violated. Local factors like 
third degree burns, trauma and wounds, surgery, intravenous drug abuse may prove favourable for deep invasion.

To find an affective Ayurvedic remedy for the treatment of the candidiasis Gandhaka rasayana is selected for the study. Gandhaka Rasayana is one of the important formulations used in the treatment all types of kusthas (skin diseases), nadivrana (sinuses) and kostha gata roga (Gastrointestinal disorders). Thus based on its use on certain skin diseases, since ancient times, the present study "In-Vitro Anti-Fungal Activity of Gandhaka Rasayana" was undertaken to prove its efficacy as an Antifungal agent especially on Candida albicans.

\section{Aims and objectives:}

- To carry out Purification of the raw drug - Gandhaka (sulphur) and.

- To prepare Gandhaka Rasayana

- To find the Anti-fungal action of the prepared Gandhaka Rasayana and

- To determine the Minimum inhibitory concentration (MIC) \& Minimum Fungal dosage (MFD) of prepared sample against Candida albicans.

Materials and methods:

Raw materials were collected from genuine sources and subjected initially for the purification process.

Gandhaka Shodhana (Purification of Sulphur ):(1) (Rasa ratna samuchaya 3/2123)

Materials: Gandhaka - 500 gm (Figure 1), Godugdha - 2 lts, Mud pot, Sthali yantra, Cloth, lace or wire.

Method: Bhudhara method (Figure 2)

Procedure: A mud pot was taken and filled with 2 1ts of Godugdha (Cow milk) and a cloth is tied to the mouth of the pot with a lace or wire. On the cloth $500 \mathrm{gm}$ of Gandhaka was placed and is covered with
Sthali yantra (Lid). Then the pot is placed in a pit made in the ground such that the pot along with the lid exactly fits into it. Then it is covered with sufficient number of Vanyopalas (Cow dung cakes). The cow dung cakes are then burnt till they become ash. The Gandhaka melts and drops into the milk leaving the impurities in the cloth. After the ashes get self cooled, the mud pot is taken from the pit and the Gandhaka is collected from the milk and washed in hot water. Thus the pure Gandhaka (Figure 3), devoid of impurities is obtained. This is used for the preparation of the compound Gandhaka Rasayana.

\section{Observations:}

\begin{tabular}{|l|l|l|}
\hline Gandhaka & $\begin{array}{l}\text { Before } \\
\text { shodhana }\end{array}$ & $\begin{array}{l}\text { After } \\
\text { shodhana(b) }\end{array}$ \\
\hline Weight & $500 \mathrm{~g}$ & $496 \mathrm{~g}$ \\
\hline Appearance & $\begin{array}{l}\text { Yellow, } \\
\text { crystalline }\end{array}$ & $\begin{array}{l}\text { Small } \\
\text { globular and } \\
\text { lustrous }\end{array}$ \\
\hline
\end{tabular}

\section{Preparation of Gandhaka Rasayana:(5)}

Materials:

- Suddha gandhaka (purified sulphur),

- Godugdha (Cow Milk),

- Chaturjata Kwatha (Decoction prepared by the combination of Tvak (Cinnamonum zeylanicum Lume.), Patraka (Cinnamum tamala Nees.), Ela (Elettaria cardamomum Maton.) and Nagakesara (Mesua ferrea)),

- Guduci swarasa (Juice of the leaves of Tinospora Cordifolia),

- Triphala kwatha (Decoction prepared by the combination of the fruits of Hareetaki (Terminalia chebula), Vibhitaki (Terminalia belerica) and Amalaki (Phyllanthus embelica)),

- Sunthi kwatha (Decoction of dried ginger (Zingiber officinalis), 
- Bhringaraja swarasa (Juice of the whole plant of Eclipta alba) and

- Ardraka swarasa (Juice of the wet rhizomes of Zingiber officinalis)

- Kharala yantra

Method: Bhavana (Trituration)

Procedure: Suddha gandhaka (purified sulphur) was subjected to bhavana (trituration) first with Godugdha (Cow milk) followed by the trituration with Chaturjata Kwatha, Guduci swarasa, Triphala kwatha, Sunthi kwatha, Bhringaraja swarasa and Ardraka swarasa, for 8 times each. Then the Gandhaka is collected and mixed with equal quantity of Sugar and preserved in an airtight bottle. This compound is called as Gandhaka Rasayana.

\section{Anti Fungal Study:}

After the drug is prepared, the antifungal study was conducted in MICROBIOLOGY DEPARTMENT OF JSS MEDICAL COLLEGE, MYSORE. The study is as follows.

Procedure to know the Minimum Inhibitory Concentration (MIC):

Preparatory procedures:

A) To make Gandhaka Rasayana suitable for the study, it was made into fine powder and stock solution was prepared by adding $10 \mathrm{ml}$ of BHI broth (Figure 5) to $100 \mathrm{mg}$ of Gandhaka rasayana. The stock solution was then diluted to prepare three different samples of different concentration of the drug and were named as follows.

Sample I - Containing Gandahaka Rasayana in a concentration of 10 $\mathrm{mg} / \mathrm{ml}$ of the BHI Broth.

Sample II - Containing Gandahaka Rasayana in a concentration of $5 \mathrm{mg} / \mathrm{ml}$ of the BHI Broth.

Sample III - Containing Gandahaka Rasayana in a concentration of 2.5 $\mathrm{mg} / \mathrm{ml}$ of the BHI Broth.
B) Control groups: Two solutions named as positive control group and negative control group were taken as follows:

Positive control group: In which fungal suspension was maintained to check the viability of organisms.

Negative control group: Was only BHI broth for validation of the test was used.

C) A suspension was prepared with standard strain of Candida albicans matching to $0.5 \mathrm{Mc}$ Farland turbidity standards.

\section{Method:}

To study the antifungal activity, Invitro study by Broth Dilution Method was adopted. In this five test tubes were taken and filled with $1 \mathrm{ml}$ of the samples of Sample I, sample II, Sample III, Positive control group and Negative control group respectively. To the test tubes named as Sample I, Sample II and Sample III, 1 loop full of Candida albicans matching to $0.5 \mathrm{Mc}$ Farland turbidity standards was added. Then all the five test tubes (sample group and control group) were incubated at $37^{\circ} \mathrm{C}$ for 24 hrs.

After $24 \mathrm{hrs}$ of incubation, the test tubes were taken out on wet mount separately for each sample and were examined microscopically for viability of the Candida. Then one loop full of material was taken out from each test tube aseptically and inoculated on five different Sabouraud's dextrose agar (SDA) plates separately for the sample groups and the control groups respectively. All the plates were then incubated at $37^{0} \mathrm{C}$ for 24 hours to promote the fungal growth.

On the third day the plates were examined for presence or absence of fungal growth (colony formation).

\section{Procedure adopted to know the Minimum Contact Time (MCT):}

$5.0 \mathrm{mg}$ of the prepared sample (Gandhaka Rasayana) was added to $5 \mathrm{ml}$ of 
BHI broth containing Candida albicans. Subcultures were prepared from the solution at different times i.e., immediate, after halfan-hour, one hour, one and half hour, two hours, two and half hours, three hours and four hours, on the SDA (Sabouraud's dextrose agar) and were incubated at $37^{\circ} \mathrm{C}$ for 24 hours for the viability of the Candida. After 24 hours, the SDA media was examined for the growth of the fungi.

\section{Observations and results:}

\section{Minimum Inhibitory Concentration} (MIC): (Table 1)

After 24 hours of incubation of SDA plates, positive control group and the Sample III were showing the growth of the Candida (Figure 6), indicating that the Candida were viable through out the experiment and the Concentration of Gandhaka Rasayana at $2.5 \mathrm{mg} / \mathrm{ml}$ of BHI Broth was not sufficient to inhibit the growth of the Candida. Thus it can be said that the Minimum Inhibitory Concentration (MIC) of Gandhaka Rasayana for Candida is $5 \mathrm{mg} / \mathrm{ml}$ of BHI Broth.

\begin{tabular}{|c|c|}
\hline $\begin{array}{l}\text { Table 1: Showing the } \\
\text { concentrations of Gat } \\
\text { the Candida cultures }\end{array}$ & $\begin{array}{l}\text { ffect of different } \\
\text { haka rasayana on }\end{array}$ \\
\hline SDA plates & Candida albicans \\
\hline Positive control group & Growth present \\
\hline $\begin{array}{l}\text { Negative control } \\
\text { group }\end{array}$ & Growth absent \\
\hline Sample I & Growth absent \\
\hline Sample II & Growth absent \\
\hline Sample III & Growth present \\
\hline
\end{tabular}

Minimum Contact Time (MCT): (Table 2)

It was observed after 24 hours of incubation that the growth of Candida was seen till half an hour of the adding of the Gandhaka Rasayana and was absent later. This indicates that the minimum contact time (MCT) of Gandhaka Rasayana to act anti-fungally should be above one hour.

Table 2: Showing the Effect of Gandhaka rasayana on the Candida cultures inoculated at different times

\begin{tabular}{|l|l|}
\hline $\begin{array}{l}\text { Time of subculture after } \\
\text { inoculation }\end{array}$ & Growth \\
\hline $\begin{array}{l}\text { Immediately after adding } \\
\text { sample }\end{array}$ & Present \\
\hline Half an hour & Present \\
\hline One hour & Absent \\
\hline One \& Half hour & Absent \\
\hline Two hours & Absent \\
\hline Two \& Half hour & Absent \\
\hline Three hours & Absent \\
\hline Four hours & Absent \\
\hline
\end{tabular}

Discussion and conclusion:

Ayurvedic System of medicine has its long history of therapeutic potential. Many drugs used by the Ayurvedic physicians have good therapeutic efficacy, but they lack scientific validity regarding the standard dosage patterns and the duration of the treatment to be adopted. Hence an experimental proof in this will help the mankind to use the medicine much efficaciously in the therapeutic practice.

In the present study, Gandhaka Rasayana, a well known Ayurvedic compound was taken for the in-vitro antifungal study especially on the Candida albicans. Gandhaka Rasayana has a wide range of therapeutic actions as mentioned in the Ayurvedic classics. It is used in diseases like Kushta, Kandu etc., which show a clear involvement of bacterial and fungal activity. Thus the drug is selected for the study to know its anti-fungal activity.

Candidiasis is the most common mycotic disorder affecting the immunecompromised patients like Diabetes, AIDS, 
post-transplat cases etc. So for this study, Candida albicans was selected from the fungal organisms as it is the most common cause of the candidiasis.

Standard sample of the Gandhaka Rasayana is prepared and is used. Broth dilution method was adopted to know the Minimum inhibitory concentration (MIC) and the Minimum Contact Time (MCT).

From the above study it was observed that the Minimum inhibitory Concentration of the of Gandhaka Rasayana on the Candida cultures is above $5 \mathrm{mg} / \mathrm{ml}$ of the BHI Broth and the minimum Inhibitory Concentration is above one hour.

Thus it can be concluded that Gandhaka Rasayana has the anti-fungal activity on Candida albicans organisms when studied in-vitro.

Further research has to be carried out to find out the effect of Gandhaka Rasayana on Candida albicans and to know its effects in-vivo and complications of using the drug.

\section{REFERENCES:}

1. Satpute D. Ashok, Rasa Ratna Samucchaya of Vagbhatta Acharya, First Edition, Delhi; Chaukamba Sanskrit Pratishthan; 2003. p. 316-PP3.

2. Acharya Panashara Radhakrisna, Sharangdhara Samhita of Sharangdhara, Fourth Edition, Allahabad; Shri Bhaidyanath Ayurved Bhavan Ltd.; 1994. p.612

3. Indradeva Tripathi, Rajanighantu of Pandit Narahari, Fourth Edition, Varanasi, Chowkhamba Krisnadas Academy; 2006. p.708

4. Chunekar K.C, Pandey G.S, Sri Bhavaprakasa Nighantu of Bhavamishra, First Edition, Varanasi;
Chaukhambha Bharati Academy; 2006. P.984

5. Gulrajsharmamishra, Ayurveda prakasha of Madhav upadhyaya, Varanasi;2 ${ }^{\text {nd }}$ Edition Chaukamba Vishwabharati;1999 p.504

6. Baveja,C.P, Text book of Microbiology, Second Edition, New Delhi; Arya Publication; 2005. p.626

7. Anonymous, Pharmacopoeial Standards for Ayurvedic Formulations, Revised Edition, New Delhi; CCRAS; 1987.

8. Ananthanarayanan R, C. K. Textbook of Microbiology, $4^{\text {th }}$ Edition, Madras; Jayaram Paniker, Orient Longman Limited; 1990.

9. Ghosh B. N, Pharmacology, Materia Medica and Therapeutics, $18^{\text {th }}$ Edition, Hilton \& Co;

10. Nadakrani K.M, Nadakarni A.K, Indian Materia Medica Volume II, $2^{\text {nd }}$ Edition, Bombay; Popular Prakashana; 1992. P.47

11. Satoskar R.S. and Bhandarkar S.D., Pharmacology and Pharmacotherapeutics, $12^{\text {th }}$ Edition, Bombay; Popular Prakashan; 1991.

12. Behl P.N, Practice of Dermatology, New Delhi; CDS Publishers; 1988.

13. Harrison; Principles of Internal Medicine, $17^{\text {th }}$ Edition, USA; McGrawHill Publication; 2009.p.2607

14. Clayton Thomas-Taber's Cyclopedic Medical Dictionary, Edi. XVIIIth, 1998,

15. Jaypee Brothers Medical Publishers, New Delhi.

16. Norman Evers G. D, Elsdon. C., The analysis of drugs and chemicals, Company Ltd; 1929.

17. Davidson, Davidson'Principles and Practice of Medicine, $18^{\text {th }}$ Edition, Great Britain; ELBS; 1999.p.1381 


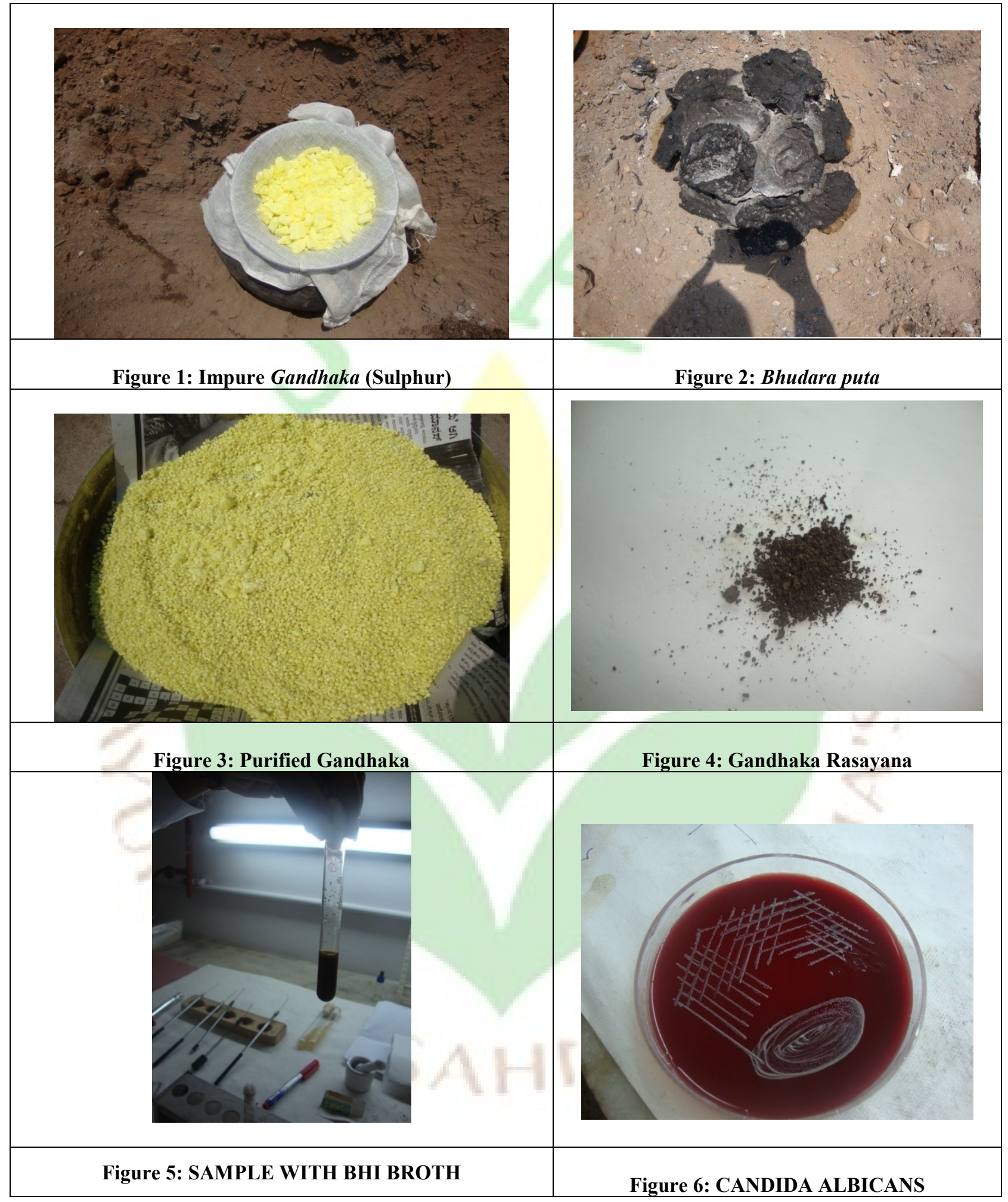




\section{Figure 7: Subculture of Candida on SDA at different intervals of time}

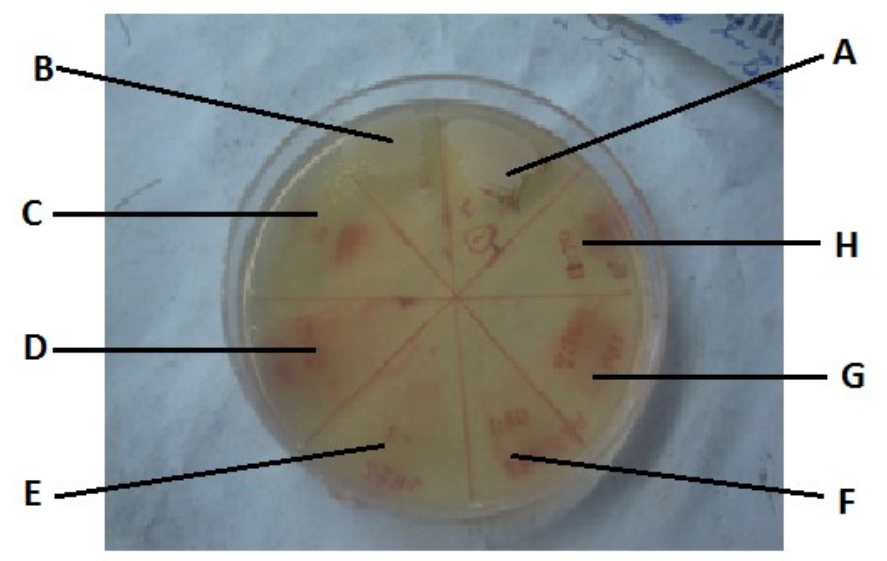
A. Immediately after adding sample
C. After One hour
E. After Two hours
G. After Three hours

B. After half an hour

D. After One \& Half hour

F. After Two \& Half hour

H. After Four hours

$* * * * *$ 